\title{
Policy recommendation on whaling, trade and watching of cetaceans (Mammalia Cetacea) in the Republic of Korea
}

Miyeon Kim, Hoa Quynh Nguyen, Yoonjung Yi, Jaeha Ahn, Ye Eun Kim, Soojin Jang, Sanha Kim, Sungsik Kong \& Amaël Borzée*

Most of the cetacean (Mammalia Cetacea) species are endangered due to various past human activities and most of these species are still under threat due to the same reason. We recommend the development of policies regarding whaling, trading and watching of cetaceans in the Republic of Korea. We recommend the restriction of trade in marine mammals, whether for human consumption or for entertainment purposes, and the development and adoption of ethical rules for marine mammal watching activities.

KEY WORDS Policy recommendation; conservation; cetacean; Republic of Korea.

Received 07.12.2018; accepted 21.02.2020; published online 20.03.2020

\section{INTRODUCTION}

Most cetacean species are under threat, as a result of past human actions (Brito et al., 2017; Hofman, 2017), and although measures were taken, a number of species is still declining (Avila et al., 2018). As a measure for whale protection, parties of the International Whaling Commission (IWC) voluntarily ratified a moratorium banning commercial whaling in 1986 but allowed special exceptions in the case of scientific research. Additionally, whales are also listed under the Appendix 1 of the Convention on International Trade in Endangered Species of Wild Fauna and Flora (CITES Appendix 1). Despite a few countries not adhering to the moratorium of the IWC, several governments have found it too lax and reinforced the legal protection for whales. For instance, importing wild-caught cetaceans is banned in Finland since 2003, and in Mexico since 2006 (Ordorica, 2003; Mexico Wildlife Law, 2006; Alaniz, 2008). Since 2007, dolphins originating from Taiji, Japan are banned in the Dominican Republic (WDC, 2007), and since 2012 marine mammals cannot be kept for entertainment purpose in Switzerland (Swiss Parliament, 2012). The Republic of Korea has also reinforced the guidelines of the IWC moratorium, although these additional laws do not prevent illegal whaling practices through by-catch and whale meat trade (Choi, 2018; Park, 2018), nor the consideration of beginning whaling for "scientific research" (Kang, 2012). Here, we suggest a reinforcement of policies for live trade, meat trade, husbandry, consumption, and tourism in the frame of integrated cetacean conservation.

\section{DISCUSSION}

\section{Trade and breeding of live animals}

Dolphins have been used for entertainment purposes in the Republic of Korea since 1984 (Nam, 2017a). From then on, Bottlenose Dolphins (Tur- 
siops sp.) used in the industry originate principally from Japan, while Indo-Pacific Bottlenose Dolphins, Tursiops aduncus (Ehrenberg, 1833), are locally caught, and Belugas are imported from Russia (Lee, 2017). As of October 2019, a total of 38 cetaceans were held captive in eight aquariums in the Republic of Korea (Hotpinkdolphins, 2019). The last specimens imported were two Bottlenose Dolphins in January 2017, accommodated at the Jangseong-po Whale Museum and Whale Experience Hall, Ulsan, and one of the two specimens died within five days of arrival (Nam, 2017b). Because of negative popular press, and in response to the death, several Korean NGOs created the "Cetacean Captive Facility Report". This report highlights that the average life expectancy for captive cetaceans in Korea is 4 years, compared to 40 to 50 years in the wild (Lee, 2017). As a result, the Korean Ministry of Environment banned both the importation of live cetaceans captured from Taiji, Japan, and "erroneously captured" individuals (Ministry of Environment, 2018). However, importation from other localities is still legal, without the quantitative assessment of captures, or the definition of legal conditions of capture. Finally, the current cetacean breeding program still lacks strict regulation.

In view of the information presented above and under the current situation, we recommend a ban on the import of any marine mammal for entertainment purposes, especially for species requiring high housing standards in captivity. It is also essential to update the laws on this topic and improve the quality of the farms of all the specimens still in captivity.

\section{Meat trade and consumption}

Whale and dolphin meat is readily available along the south-eastern coast of the Korean peninsula (Kang \& Phipps, 2000), allegedly originating from legal catch and by-catch (Mills et al. 1997). It is affecting cetacean populations in the waters exploited by the Republic of Korea and nearly resulted in a local extirpation. The population size of Finless Porpoises, Neophocaena asiaeorientalis (G. Cuvier, 1809), dropped from an estimated population size of 36,000 individuals to 13,000 between 2004 and 2011, with an additional 7,869 individuals killed between 2011 and 2016 (Heo, 2017). As a re- sult, the Finless Porpoise was designated as a Marine Protected Species on 29 September 2016, legally forbidding trade from 2017 (Ministry of Ocean and Fisheries, 2016). However, 792 cases of by-catch were reported in 2018 (Ministry of Ocean and Fisheries, 2019), a number estimated to be between 5000 and 7000 individuals by official dolphin meat traders (Lee, 2019a).

In addition, evidence shows a mismatch between whale meat reported as by-catch and the amount offered for sale. This is the result of illegal whale meat entering the market (Baker et al. 2006; Baker et al. 2010). For instance, over $700 \mathrm{~kg}$ of whale meat disguised as shark meat entered the country in 2018 (Kim 2018). Also, more than 53 marine mammals were illegal caught, by an estimated 30 illegal whaling vessels in Korean waters, and traded between 2014 and 2018 (Lee 2019b).

The consumption of the cetacean meat maintain a demand, pressuring both illegal and legal whale and dolphin meat trade. Consequently, we recommend banning the sale of all cetacean meat to eliminate any sales of disguised illegal by-catch of species that cannot be legally hunted, and alleviate hunting pressure on legally hunted species.

\section{Tourism}

Marine mammal watching is a recognised profitable industry, with very clear benefits for education and thus conservation when conducted appropriately (Foxlee, 2001; Lück, 2003; Mayes et al., 2004). However, tourism based on marine mammal watching is often conducted without strict guidelines, which can have a stronger direct negative impact than the positive output of education (Parsons, 2012). For instance, surveying research vessels reduce time spent foraging at the surface by Sperm Whales (Isojunno \& Miller, 2015); boats within a $1 \mathrm{~km}$ radius result in decreased communication in Bottlenose Dolphins (Luís et al., 2014); the sound produced by boats is correlated with the production of stress hormones in Right Whales (Rolland et al., 2012), and boat traffic from dolphin watching affects the amount of rest time available to Bottlenose Dolphins (Constantine et al., 2004). Finally, the presence of boats has been found to be related to the cause of death to one-third of stranded cetaceans in the Canary Islands (Arbelo et al., 2013) and to the decrease in breeding output in Gray 
Whales, where as little as 10 days of lost foraging opportunities due to disturbance can result in an unsuccessful pregnancy or the loss of a calf(VillegasAmtmann et al., 2015). Cetacean watching programs are being developed on Jeju Island and have been present in Ulsan for a few years. In this case, a ban on cetacean observation should not be proposed because the development of this practice can have invaluable educational and conservation results. However, the establishment of stricter rules, respecting the life of cetaceans, would be desirable. Adopting a better marine mammal observation policy can protect these populations from negative anthropogenic effects, both in the Republic of Korea and in other countries.

\section{CONCLUSIONS}

Based on the data presented above and on the critical survival situation of some cetacean species, we recommend the development of new and better policies for the conservation of marine mammals present in the territorial waters of the Republic of Korea.

In this case, all governmental and ministerial branches dealing with the environment, culture, tourism and fishing should be concerned with more frequent and efficient controls and rapid sanctions appropriate to the seriousness of the violations carried out.

These regulations and their application must be shared with all other countries that have the same problems to ensure greater protection for cetaceans worldwide.

\section{ACKNOWLEDGEMENTS}

We are grateful for comments from members of the SCB Asia section board, and especially to Jeffrey McNeely (Thailand), Tony Lynam (Australia) and Lindsay Porter (Hong Kong).

\section{REFERENCES}

Alaniz Y., 2008. Report on Mexican Dolphins in Mexico and Dominican Republic. World Society for the Protection of Animals. http://endcap.eu/wp-content/up-
loads/2015/06/WSPA_dolphins_Mexico_Republica_Dominicana.pdf.

Arbelo M., Los Monteros S.E., Herraez P., Andrada M., Sierra E., Rodriguez F., Jepson P.D. \& Fernandez A., 2013. Pathology and causes of death of stranded cetaceans in the Canary Islands (1999-2005). Diseases of Aquatic Organisms, 103: 87-99.

Avila I.C., Kaschner K. \& Dormann C.F., 2018. Current global risks to marine mammals: taking stock of the threats. Biological Conservation, 221: 44-58.

Baker C.S., Lukoschek V., Lavery S., Dalebout M.L., Yong-un M., Endo T. \& Funahashi N., 2006. Incomplete reporting of whale, dolphin and porpoise 'bycatch' revealed by molecular monitoring of Korean markets. Animal Conservation, 9: 474-482.

Baker C.S., Steel D., Choi Y., Lee H., Kim K.S., Choi S.K., Ma Y.U., Hambleton C., Psihoyos L., Brownell R.L. \& Funahashi N.S., 2010. Genetic evidence of illegal trade in protected whales links Japan with the US and South Korea. Biology letters. rsbl20100239.

Brito C., Vieira N., Jordão V. \& Teixeira A., 2017. Digging into our whaling past: Addressing the Portuguese influence in the early modern exploitation of whales in the Atlantic. Environmental History in the Making Switzerland: Springer, Cham, pp. 33-47.

Hofman R.J., 2017. Sealing, whaling and krill fishing in the Southern Ocean: past and possible future effects on catch regulations. Polar Record, 53: 88-99.

Choi C., 2018. Suspected illegal dismantling of whale found in Pohang coast. News1 Korea Seoul, Republic of Korea: News1 Korea.

Constantine R., Brunton D.H. \& Dennis T., 2004. Dolphin-watching tour boats change bottlenose dolphin (Tursiops truncatus) behaviour. Biological Conservation, 117: 299-307.

Endo T., Yong-Un M., Baker C.S., Funahashi N., Lavery S., Dalebout M.L., Lukoschek V. \& Haraguchi K., 2007. Contamination level of mercury in red meat products from cetaceans available from South Korea markets. Marine Pollution Bulletin, 54: 669-677.

Foxlee J., 2001. Whale watching at Hervey Bay. Australian Parks and Leisure, 4: 17-18.

Heo K., 2017. Crying "Korean mermaid", finless porpoises, accounting for $70 \%$ of whales being caught. Yonhap News Seoul, Republic of Korea.

Hotpinkdolphins, 2019. October 2019 Domestic Captive Marine Mammal Statues. Jeju, Republic of Korea. http://hotpinkdolphins.org/?p=19627

Isojunno S. \& Miller P.J.O., 2015. Sperm whale response to tag boat presence: biologically informed hidden state models quantify lost feeding opportunities. Ecosphere, 6: 1-46.

Kang J.-S., 2012. Opening Statement (IWC/64/OS Korea) by the Head of the Republic of Korea Delegation. South Korea statement to International Whal- 
ing Commission. https://www.scribd.com/document/ 99133406/South-Korea-statement-to-InternationalWhaling-Commission.

Kang S. \& Phipps M., 2000. A survey of whale meat markets along South Korea's coast. Hong Kong: Traffic East Asia.

Kim Y.D., 2018. Whale meat from Japan illegally smuggled in to the country as a 'shark meat'. The Hankyoreh, Seoul, Republic of Korea: http://www.hani.co. $\mathrm{kr} /$ arti/area/area_general/855753.html

Lee J., 2017. Hot pink dolphins. In: 'Care' Aro (Ed.), The Public Private Collaborative Research revealed poor management status of whale facilities Seoul, Republic of Korea: Korean Animal Welfare Association.

Lee Y.R., 2019a. Stop by-catch, if you want to protect the 'native' Finless Porpoise. The Kyunghyang Shinmum. Seoul, Republic of Korea: http://news.khan.co. kr/kh_news/khan_art_view.html?artid=20190725205 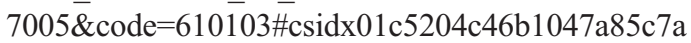 0134 cee 987

Lee B.W., 2019b. 53 whales have been illegally caught in the past five years... 31 illegal whaling vessels country wide. News Penguin: http://www.newspenguin.com/news/articleView.html?idxno $=419$

Lück M., 2003. Education on marine mammal tours as agent for conservation-but do tourists want to be educated? Ocean \& Coastal Management, 46: 943-956.

Luís A.R., Couchinho M.N. \& Santos M.E., 2014. Changes in the acoustic behavior of resident bottlenose dolphins near operating vessels. Marine Mammals Science, 30: 1417-1426.

Mayes G., Dyer P. \& Richins H., 2004. Dolphin-human interaction: Pro-environmental attitudes, beliefs and intended behaviours and actions of participants in interpretation programs: A pilot study. Annals of Leisure Research, 7: 34-53.

Mexico Wildlife Law. 2006. General Wildlife Act. Official Journal of the Federation. http://www.ifaw.org/ international/node/26476.

Mills J., Ishirhara A., Sakaguchi I., Kang S., Parry-Jones R. \& Phipps M., 1997. Whale meat trade in east Asia: a review of the markets in 1997. Cambridge, UK: Traffic International.

Ministry of Environment, 2018. Enforcement Decree of the Wildlife Protection and Management Act: Presidential Decree No. 28721, Partial Amendment enforcement on 27 March 2018. In: Ministry of Environment RoK, editor. 28721, 27 March 2018 ed Seoul, Republic of Korea: http://www.law.go.kr/ DRF/lawService.do?OC $=$ jaa806\&target $=$ law\&MS= 202923\&type $=$ HTML\&mobileYn $=\&$ efYd $=2018032$ 7
Ministry of Ocean and Fisheries, 2016. Ministry of Ocean and Fisheries, 25 additional species included as protected marine animals. 29 September 2016. Seoul, Republic of Korea: http://www.mof.go.kr/article/view.do?menuKey=376\&boardKey=10\&articleKey $=13470$

Ministry of Ocean and Fisheries, 2019. Ministry of Ocean and Fisheries, 2019 marine mammal necropsy meeting open. 08 July 2019. Seoul, Republic of Korea: http://www.nifs.go.kr/distantwater/skin/doc. html?fn=ofiris_20190708134831207.hwp\&rs=/distantwater/preview/insmaterial/

Nam J., 2017a. What happened to the seven dolphins brought back to their home? Korea has become 'dolphin welfare' developed country. The Hankyoreh Seoul, Republic of Korea: http://www.hani.co.kr/arti/ society/environment/803276.html\#csidx863864f46bf 0e4c91d5ee961356241b.

Nam J., 2017b. A common bottlenose dolphin died 4 days after being imported from Japan to Ulsan Jangsangpo dolphin museum. The Hankyoreh Seoul, Republic of Korea.

Ordorica J., 2003. Letter from Senator Ordorica to Singapore's Minister of National development. Comittee of Environment, Natural Resources and Fisheries. http://yawningbread.files.wordpress.com/2011/08/pic 201108_55.gif.

Park J.G., 2018. Gyeongbuk police arrested multi-layered illegal whaling organization involved with 700 million won worth of Minke whale illegal trade. Newsis Seoul, Republic of Korea: Newsis.

Parsons E.C.M., 2012. The negative impacts of whalewatching. Journal of Marine Biology, 807294: 1-9.

Rolland R.M., Parks S.E., Hunt K.E., Castellote M., Corkeron P.J., Nowacek D.P., Wasser S.K. \& Kraus S.D., 2012. Evidence that ship noise increases stress in right whales. Proceeding of the Royal Society B., 279: 2363-2368.

Swiss Parliament, 2012. Dolphins no longer to be kept in captivity. The Federal Assembly. https://www. swissinfo.ch/eng/dolphins-no-longer-to-be-kept-incaptivity/32293912.

Villegas-Amtmann S., Schwartz L.K., Sumich J.L. \& Costa D.P., 2015. A bioenergetics model to evaluate demographic consequences of disturbance in marine mammals applied to gray whales. Ecosphere, 6: 19.

WDC, 2007. Statement concerning the import ban for wild dolphins to Dominican Republic. Whale and Dolphin Conservation http://us.whales.org/news/ 2007/12/statement-concerning-import-ban-for-wilddolphins-to-dominican-republic. 